\title{
THE STUDENTS' EYESIGHT ON THE EFFECTIVENESS OF REMOTE LEARNING DURING THE COVID-19 PANDEMIC
}

\author{
Annisa Shofa Tsuraya ${ }^{1 *}$, Multazam Abubakar ${ }^{1}$, Muthi'ah $^{1}$ \\ Department of English Education, Faculty of Tarbiyah and Teacher Training, \\ Universitas Islam Negeri Alauddin Makassar \\ Sultan Alauddin Street No. 63 Gowa, South Sulawesi, Indonesia. 92113 \\ Email:*annisa.tsuraya@uin-alauddin.ac.id; multazam.abubakar@uin-alauddin.ac.id; \\ muthiah.rahim@uin-alauddin.ac.id
}

\begin{abstract}
The world is paralyzed. In the beginning of 2020, the earth is attacked by COVID-19 pandemic. This pandemic has a massive impact towards all sectors in human daily life. All communication way shift to online communication include teaching and learning process. This research was aimed at evaluating the effectiveness of remote learning in the midst of a COVID-19 pandemic. This research applied qualitative method. The subject of this research are the English department students of a state university in Makassar, Indonesia. Openresponse questionnaire was chosen as the instrument to gain the data. Thus, the pandemic of COVID-19, the researcher spread the questionnaire through Google Form. From the questionnaire, the result showed that the majority of students did not like remote learning. They did not enjoy the teaching and learning program such as discussion class or when they wanted to communicate with their friends and lecturers. There felt some obstacles in creating a real teaching and learning English condition through remote learning due to the unsupported device and unstable internet networks. It can be concluded that Indonesia has not ready yet to apply the remote learning as the standard learning system due to the uneven welfare and the spread of stable internet networks. This condition also possible drives students to some psychological disorders such as anxiety and under pressure. The lesson learned from this COVID-19 pandemic will make the next generation, remote learning platforms, and solutions for future cases more ready and better than today.
\end{abstract}

Keywords: COVID-19, EFL learners, online education, remote learning, pandemic

\begin{abstract}
Abstrak: Dunia lumpuh. Di awal tahun 2020, bumi sedang dilanda pandemi COVID-19. Pandemi ini berdampak besar pada semua sektor dalam kehidupan sehari-hari manusia. Semua cara komunikasi bergeser ke komunikasi online termasuk proses belajar mengajar. Penelitian ini untuk mengevaluasi efektivitas pembelajaran jarak jauh di tengah pandemi COVID-19. Penelitian ini menggunakan metode kualitatif. Subjek penelitian ini adalah mahasiswa Jurusan Bahasa Inggris salah satu Universitas Negeri di Makassar, Indonesia. Kuesioner respon terbuka dipilih sebagai instrumen untuk memperoleh data. Dengan demikian, pada masa pandemi COVID-19, peneliti menyebarkan kuesioner melalui Google Form. Dari angket diperoleh hasil bahwa sebagian besar siswa tidak menyukai pembelajaran jarak jauh. Mereka tidak menikmati program belajar mengajar seperti kelas diskusi atau ketika mereka ingin berkomunikasi dengan teman dan dosen mereka. Ada beberapa kendala dalam menciptakan kondisi belajar mengajar Bahasa Inggris yang nyata melalui pembelajaran jarak jauh karena perangkat yang tidak mendukung dan jaringan internet yang tidak stabil. Dapat disimpulkan bahwa Indonesia belum siap untuk menerapkan pembelajaran jarak jauh sebagai sistem pembelajaran standar karena kesejahteraan yang tidak merata dan penyebaran jaringan internet yang stabil. Kondisi ini juga memungkinkan siswa mengalami beberapa gangguan psikologis seperti kecemasan dan tekanan. Pelajaran dari pandemi COVID-19 ini akan membuat generasi berikutnya, platform pembelajaran jarak jauh, dan solusi untuk kasus masa depan lebih siap dan lebih baik dari saat ini.
\end{abstract}

Kata Kunci: COVID-19, pandemi, pelajar EFL, pembelajaran jarak jauh, pendidikan online

\section{Introduction}

The COVID-19 pandemic has a profound effect towards the world condition. This outbreak hits various sectors in human life. It breaks the economic system, many stores and markets are closed, some business are ruin, so that there are many people lost their jobs during this pandemic. The worst part is it breaks the educational system, the schools and universities are closed. All people have to do lockdown and this condition drives people, especially children into stressful feeling because they get this attack for the first time in their era. This is also in accordance with the advice of the Prophet as stated in the hadith below. 
Meaning:

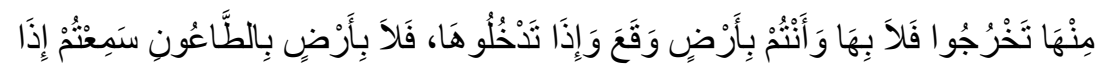

"Ifyou hear of a plague in an area, then do not enter it. But if there is an epidemic where you are, then don't leave that place." (Hadith by Bukhari).

The education system in Indonesia is based on traditional and modern classroom education and requires the pupils to attend the school classes every day. The situation in general education in this country has changed in the beginning semester of 2020, when the first case of COVID-19 infection was detected in Indonesia. The virus has infected 1,504,971 persons worldwide (Basilaia \& Kvavadze, 2020) and by June 272020 there are 51,427 cases in Indonesia as reported by the Indonesian Minister of Health. Researchers at Imperial College in London, estimate the global impact in the year 2020 to range between 20 million deaths, with effective non-pharmaceutical interventions in place, and 40 million deaths, without such interventions (Walker et al., 2020).

As carried out by many countries to prevent transmission of the corona virus in the schools, and universities, the Indonesian Minister of Education and Culture issued a circular number 4 of 2020 which regulates the implementation of education in the emergency period of the spread of corona virus. This Learning from Home (LFH) policy is appropriate to prevent the spread of COVID-19 in the educational environment. Automatically, all face to face teaching and learning processes are done through online education.

The development of information and communication technology in the Industrial 4.0 era has had a great influence on the teaching and learning process. Easy access to technology has been used by teachers to improve the quality of education. As stated by Keengwe \& Georgina (2012) in their research, it has been stated that technological developments have changed the implementation of teaching and learning. Information technology can be accepted as a medium in conducting educational processes, including assisting in teaching and learning, which also involves searching for references and sources of information (Wekke \& Hamid: 2013).

In line with the development of technological advances, many language educators have used technology to improve language teaching both in formal educational institutions of Islamic boarding school ranging from high schools to universities. Technology has many effects on language learning (Gheytasi et al., 2015). The internet has been integrated as a tool to complement language learning activities (Martins, 2015).

The physical classroom is starting to lose its main role in monopolizing the place of learning. The internet has made significant changes to almost all aspects of our lives ranging to sources of information, news, and learning. In a situation where the students are not allowed to go to school, the alternative is to move from traditional to online education. In this case the essential parts are the internet coverage, availability of computers or smartphones in the population. It is imperative that researchers and educators examine the effectiveness of online learning in educating students compared to traditional face-to-face learning. Thus, this research addresses the evaluation of how effective remote learning in educating students as the representative of traditional learning.

There have been some studies on remote learning or well-known as online education that find positive statistically significant effects for student learning outcomes in the online format compared to the traditional face-to-face format. Some of the positive learning outcomes are improved learning as measured by test scores, student engagement with the class material, improved perception of learning and of the online format, stronger sense of community among students, and reduction in withdrawal or failure.

Riffell \& Sibley (2005) in Nguyen (2015) in their study gave an illustration, Jean-Luc was an archeologist who needed to fulfill a general science course to graduate. He had not performed well in a traditional science course and when he saw there was a hybrid environmental biology course that included bi-weekly online assignments in lieu of the traditional lecture, he thought this might work better for him. He found that the online assignments gave him time to think and reflect about the materials better than the traditional lectures. This led him to understand the ideas more thoroughly, which allowed him to 
participate more during face-to-face active-learning exercises. He also felt that he had more meaningful online and in-person interactions with the professor since he was able to participate more than he usually did in a science class. As a result, Jean-Luc had a deeper understanding of environmental biology and he did well in the class, above the average performance of his face-to-face counterpart and well above what he expected from himself. This simple example illustrates the kind of stories that can be told in these positive studies.

Other studies with a more systematic analysis, Navarro \& Shoemaker (2000) found that student learning outcomes for online learners were as good as or better than traditional learners regardless of background characteristics and that the students were greatly satisfied with online learning. Rovai \& Jordan (2004) examined the relationship of sense of community between traditional classroom and the blended format, and they found that students in the blended format had a stronger sense of community than students in the traditional format.

Khusniyah \& Hakim (2019) in their study which described the effectiveness of online-based learning on the students' ability to understand English-language texts showed that there are differences in students' ability to understand English texts before and after the use of the web blogs. In this case, online learning assisted by the web blog has a positive influence on improving students' English reading skills. The online learning used in this study was learning that utilizes the use of web blogs. This article was a part of the report of a classroom action research which focuses on identifying the effectiveness of the online-based learning viewed from two approaches, they are the comparison of data distribution and ttest on the data before the treatments (pretest) and after the treatments (posttest).

Chick et al. (2020) in their research proposed several innovative solutions including the flipped classroom model, online practice questions, teleconferencing in place of in-person lectures, involving residents in telemedicine clinics, procedural simulation, and the facilitated use of surgical videos. Although there is no substitute for hands-on learning through operative experience and direct patient care, these may be ways to mitigate the loss of learning exposure during this time. These innovative solutions utilizing technology may help to bridge the educational gap for surgical residents during this unprecedented circumstance. The support of national organizations may be beneficial in maintaining rigorous surgical education. This research attempted to define the scope of the problem of maintaining surgical resident education while maintaining the safety of residents, educators, and patients. Within the basic framework of limiting in-person gatherings, postponing or canceling elective operations in hospitals, and limiting rotations between sites, we propose innovative solutions to maintain rigorous education.

The study of Muirhead (2000) admited that online education is new in schools and can be considered for enhancing traditional schools and home-schooling. Qi (2017) made a case study on collaborative environment for distance teaching and learning and reviewed existing platforms as well and Baiyere et al. (2016) made a project enabling and facilitating collaborative teaching in information systems and found that virtual environment should be suitable for other courses as well.

Another study was done on a case of English language teaching and learning using the virtual distance learning environment and came to the result that Virtual environments allow students to create a world that encompasses anything they can dream up. Thamarana (2016) in her research stated that interaction, simulation, and collaboration enable learning in the interactive environment. As stated by Sintema (2020) in his study that the countries that are having the limited technologies have problems in schools are not ready for the complete implementation of the countrywide online education. Sintema's study is in line with a study from Indonesia carried out by Adijaya \& Santosa (2018) which found that students face some problems to interact, not only with other students but also with lecturer. It is shown by high percentage of students' disagreement to statements that declare students' interaction in online class already support them in learning process. Likewise learning environment, students feel that learning environment in online learning less support them in learning teaching process. Thus, to help students develop their interaction and learning environment, lecturers can facilitate them by creating a group in social media to interact and boost learning environment atmosphere among class members. 
On other hands, there were many more studies that found null findings for the effects of online learning. Bernard et al. (2004) found that overall, there was no significant difference in achievement, attitude, and retention outcomes between distance education, which included online education, and the traditional face-to-face education. However, there was significant heterogeneity in student learning outcomes for different activities. Separating student learning outcomes based on synchronous and asynchronous activities, activities that have to be done at the same time or at each person's convenience respectively, showed that the mean achievement effect sizes for synchronous work were better for the traditional format, but asynchronous work favored distance education.

In other words, there are better learning outcomes in the traditional format for activities that have to be done simultaneously and better outcomes in the mediated distance format for activities that can be done at various times. Other studies have also arrived at similar conclusions. For instance, a recent systematic review comparing the learning of clinical skills in undergraduate nurse education between the online format and the traditional found that there was no significant difference between the two formats (McCutcheon et al., 2015).

There are a number of studies on online learning so far especially in the general education and ESL context for the most part. However, none of the studies was conducted in the EFL context especially in terms of learners' perception on the use of online learning amid covid-19 pandemic. It makes this research different with the studies above. This research is addressed to evaluate the effectiveness of remote learning during the covid-19 pandemic based on the EFL learners' point of views in the middle of the lack internet networking condition in Indonesia which still cannot be caught spready in every area especially in rural area. This research aimed at knowing students' perception about remote learning whether it brings them better improvement than traditional (face-to-face) learning.

\section{Materials and Methods}

This research applied a qualitative method with a case study research design. Creswell (2012) stated that the qualitative research can be taken to refer to research that is based on descriptive data that does not make (regular) use of statistical procedures. According to Moleong (2009), qualitative research is a research that intends to understand the phenomenon of what is experienced by the subject of research, such as behavior, perceptions, motivations, actions, and so forth. In qualitative research, statistics are not used to analyze the data; instead, the inquirer analyzes words (e.g., transcriptions from interviews) or images (e.g., photo-graphs). Rather than relying on statistical procedures, the qualitative researcher analyzes the words to group them into larger meanings of understanding, such as codes, categories, or themes. Also, Creswell (2014) stated that case study creates an in-depth description and analysis of a bounded system.

Respondents in this research are one hundred students from different semester level of English education department from one of a state university in Makassar, Indonesia were participated in this research. When this research was conducted, they were in pandemic situation and still joining the remote learning from each village in South Sulawesi.

The instrument used to collect the data is a questionnaire in form of open-response questionnaire due to the COVID-19 pandemic. The questionnaire distributed to the respondent through Google Form. A questionnaire is a written collection of self-report questions to be answered by a selected group of research participants. Questionnaires allow the researcher to collect large amounts of data in a relatively short amount of time (Gay et al., 2016). The questionnaire contained 10 questions; they were including 2 questions about students' interaction aspect, 3 questions about learning environment aspect, and 5 questions about teaching and learning process aspect. The data from the questionnaire then transcribed by coding, analyzing, and interpreting the data. Then, the collected data will be analyzed using Miles \& Huberman model (2014), they are (1) data collection, (2) data condensation, (3) data display, and (4) conclusion drawing/verifying. 


\section{Result and Discussion}

The questionnaire was filled out by semester 1, 3, 5, and 7 students in English education department at a state university in Makassar, Indonesia through Google Form which is one of online platforms with a total of 150 respondents. The respondents were consisted of 48 students of semester 1 (32\%), 40 students of semester $3(26.7 \%)$, 32 students of semester $5(21.3 \%)$, and 30 students of semester $7(20 \%)$. The respondent description can be seen in Table 1.

Table 1. Description of respondent

\begin{tabular}{cccccc}
\hline \multicolumn{7}{c}{ The Number of Respondents } \\
\hline \multirow{3}{*}{ Class } & Semester 1 & Semester 3 & Semester 5 & Semester 7 & Total \\
\cline { 2 - 6 } & 48 & 40 & 32 & 30 & 150 \\
& $(32 \%)$ & $(26.7 \%)$ & $(21.3 \%)$ & $(20 \%)$ & $(100 \%)$ \\
\hline
\end{tabular}

Based on the description of respondent, can be seen that first semester students were more enthusiast to give responses than other students because this was their first time had lecturing through remote learning. Meanwhile, others have been doing this remote learning even before the COVID-19 outbreak through blended learning. The questionnaire consisted of 3 parts, they were aspect of students' interaction, the learning environment, and the teaching and learning process with a total of 10 questions. Below were the results of respondents' responses.

\section{A. Aspect of Students' Interaction}

Based on students' answer in the questionnaire illustrated that students showed an eyesight of disagreement when it is said that student interaction in remote learning has supported them in learning. This was evidenced by the reasons they gave when responding to the questionnaire that they had problems communicating with fellow students and lecturers. The possibility of miscommunication and misunderstanding is common. As for the interaction with lecturers, students feel that the lecturer becomes a slow response when they ask questions compared to when they face to face in the classroom. Thus, this aspect of interaction also automatically affects aspects of the student learning process. Overall, students feel that interaction through remote learning is less effective in developing students' language skills. Here were the students' perception of remote learning towards students' interaction:

St. 1: Yes, during online lecturing, we cannot communicate smoothly because it is usually interrupted by the network.

St. 2: Yeah, I often find difficulty to communicate with my classmates. Sometimes if we have a group assignment and we have to discuss about it, we often find difficulty because the other members have a bad network connection.

St. 3: I feel difficult, moreover if the network connection is unstable. And also, when we have group discussion about assignment there is always our friend cannot join as soon as possible so we cannot start the discussion and it wastes time and the discussion become ineffective.

St. 4: Yes, I feel difficult in communicating with my classmate because I or they have bad network. connection.

St. 5: In my opinion, it is difficult, because in discussing and sharing opinions about task is very uncomfortable if it's done via chat. I feel difficult in carrying out the assignment.

Students' responses expressed that during remote learning, they experienced difficulties in establishing and building social interactions because of the unstable network connection. It was in line with a study carried out by Adijaya \& Santosa (2018) which found that students face some problems to interact, not only with other students but also with lecturer. Network connection is one of the Indonesia problems in realizing remote learning. Not all areas in Indonesia are covered by stable internet connection. Some areas are not even reached by the electricity. So, in harmony with Sintema (2020) in his study that the countries that are having the limited technologies have problems in schools are not ready for the complete implementation of the countrywide online education. 


\section{B. Aspect of the Learning Environment}

Students' perceptions based on the responses of the questionnaire indicated that remote learning creates an unconducive learning environment. Students feel that this remote learning is less effective because the delivery of the point of the materials is not conveyed well. Not only due to the unstable network connection, but also because of the capability of several lecturers in using technology is still poor. Overall, students feel that learning through remote learning is less conducive in developing students' language skills. Here were the students' perception of remote learning towards learning environment:

St. 1: So far, I find it difficult to understand some of the given materials given, because there are some lecturers who just give us assignments directly without giving explanation of the materials. And only teach through WA. Only text instruction without explanation.

St. 2: Understand the learning material very well, of course not. But understand even though not the whole explanation is still possible. Because sometimes, the network is barrier, where when the lecturer explains, his/her sound sinks up due to the unstable network connection. So that, the explanation presented by the lecturer is skipped.

St. 3: Not always, depends on the teaching method applied by the lecturer. I think presentation and discussion method is more effective than we were only given a module then given assignments to do. Because during this online learning, the lecturer just give instruction, assignments, through Google Classroom. I feel I can be more understand if we learn through video conference.

St. 4: Not all. Because it depends on the lecturer. If the lecturer uses a good teaching method and give us a good materials explanation, we can understand it easier. And vice versa.

St. 5: In understanding the given materials, I need to read it two till three times to understand well and clearly because only several of the lecturers explained about the materials. Others, just give assignments without explanation.

From the aspect of the learning environment, mostly students feel that remote learning is less effective for transferring knowledge. It is also caused by the lecturers' competencies in applying teaching method through remote learning and also their poor capability in using technology. This goes along with Kadir (2018) stated that this requires lecturers to be able to prepare their competences optimally. Lecturers are the key in every effort to improve the quality, relevance and efficiency of education. Agree with Suryanto \& Jihad (2013) expressed that the ability of lecturers to carry out their role as facilitators is provide facilities for students in the teaching and learning process, guide students who experience difficulties during the teaching and learning process, and provide good examples to students. This lecturers' capability in using technology in this case the application for teaching through remote learning also gives impact to the teaching and learning process.

\section{Aspect of the Teaching and Learning Process}

According to the questionnaire response, it described that students faced obstacles in teaching and learning process. It was not only affected by the not well-established social interaction or the poor capability in using technology by several lecturers, but also the unstable network connection, financial issue, and also the unacceptability in implementing remote learning. Overall, students feel that interaction through remote learning is less effective in developing students' language skills. Here were the students' perception of remote learning towards teaching and learning process:

St. 1: I feel that face-to-face lectures are still more fun than online lectures because I don't have to buy internet data package all the time and I don't have to be busy looking for the stable network connection to attend the online lectures.

St. 2: I don't like online learning because in my village it's hard to find the stable network, connection which affect my learning process. Sometimes, I can't attend the class because of the network connection. It also consumes much money because I have to buy internet data package all the time.

St. 3: I personally disagree with online learning because mostly my friends and I myself face difficulties in attending the class due to the unstable network connection. We live far from the city. It really bothers 
us when we pay attention, listen to the lecturer explanation but suddenly the connection is lost and disconnected. We can't learn well, we can't understand the materials well, and we can't submit the assignments o on time.

St. 4: Online learning is good if the lecturer knows how to use the application well and the used application doesn't consume much internet data packege. Some lecturers, with the reason to save students internet data package, they use WA.WA consumes less internet data package but sometimes I can't understand well because too many chats, sometimes the chats are drowning then I missed the explanation. In my opinion, we can use Google Meet. It doesn't consume too much internet data packeage and feels like face-to-face learning.

St. 5: To be honest, I don't like online learning because it's hard for me to find the stable network connection and it consumes much internet data packeage. I do wan to learn well, want to listen to the lecturer's explanation clearly, want to do the assignment perfectly but I can't because of the network connection.

Those students' responses illustrated that their teaching and learning faced some obstacles which not only caused by the not well-established social interaction or the poor capability in using technology by several lecturers, but also the unstable network connection, financial issue, and also the unacceptability in implementing remote learning.

Why did students feel difficult to buy internet data package? Because during this pandemic COVID19, there are some students whose parents are fired from their job, while they have to pay their fee tuition fully and get addition by buying internet data package also. Students want the lecturers to use a proper learning application but it is light application so that just consumes a little bit internet data package. This result goes similar with Mamattah (2016) that the majority of the respondents think it is more expensive to offer courses through e-learning than fully face-to-face learning, it can be deduced that if decisions about choice of learning mode were to be made based on cost most of the respondents will go for fully classroom learning than e-learning.

\section{Conclusion}

Based on the result of this study, it can be concluded that the students' eyesight on remote learning is not good and ineffective in establishing social interaction with students and lecturers, in delivering the teaching and learning process during the lectures, and in the students' financial issue. Students hope that in this remote learning, the lecturers keep teaching like they teach in face-to-face class by using video conference application which consumes the light internet data package. They hope the lecturers not only give assignments, but also give a clear explanation about the materials.

This pandemic COVID-19 drives the students to be more active in learning by exploring anything by their own selves to be more honest to own self in doing the assignments. It also drives the lecturers to learn a new way in teaching, make them more creative in delivering the teaching materials, and force them to learn how to use technology well and the proper teaching application which suitable with the given materials and students' condition.

The lesson learned from the pandemic of 2020 will force a generation of new laws, regulations, platforms and solutions for future cases, when the countries, government and population will be more prepared than today. The study is important for the future because it shows the case of a country that has used the available free tools to transit the face-to-face learning to the remote learning during the pandemic. Online learning needs to re-arrange the exams and home assignments to the open book principle that is not developed and popular for now. Preparing new kinds of such assignments in all subjects will need additional work. The problem of grading is actual when the students stay outside of the university and new technologies have to be considered for anti-plagiarism and avoiding cheating. The quality of the learning online needs future study. Currently there was no time to get into details of quality assurance of the online teaching method as the main goal was to save the education process and continue it in any possible format. 


\section{References}

Adijaya, N., \& Santosa, L. P. 2018. Persepsi mahasiswa dalam pembelajaran online. Wanastra 10(2): 105-110. https://doi.org/10.31294/w.v10i2.3931.

Baiyere, A., \& Li, H. 2016. Application of a Virtual Collaborative Environment in a Teaching Case. In AMCIS 2016: Surfing the IT Innovation Wave - 22nd Americas Conference on Information Systems.

Basilaia, G., \& Kvavadze, D. 2020. Transition to online education in schools during a SARS-CoV-2 Coronavirus (COVID19) pandemic in Georgia. Pedagogical Research 5(4): 1-9. https://doi.org/10.29333/pr/7937.

Bernard, R. M., Abrami, P. C., Lou, Y., Borokhovski, E., Wade, A., Wozney, L., ... Huang, B. 2004. How does distance education compare with classroom instruction? A Meta-analysis of the empirical literature. Review of Educational Research 74(3): 379-439.

Chick, R. C., Clifton, G. T., Peace, K. M., Propper, B. W., Hale, D. F., Alseidi, A. A., \& Vreeland, T. J. 2020. Using technology to maintain the education of residents during the COVID-19 Pandemic. Journal of Surgical Education 77(4): 729-732. https://doi.org/10.1016/j.jsurg.2020.03.018.

Creswell, J. W. 2012. Educational Research: Planning, Conducting, and Evaluating Quantitative and Qualitative Research. Boston: Pearson Education, Inc.

Creswell, J. W. 2014. Research Design: Qualitative, Quantitative, and Mixed Method Approaches (4th ed.). London: Sage Publications.

Gay, L. R., Mills, G. E., \& Airasian, P. W. 2016. Educational Research: Competencies for Analysis and Applications. United States of America: Pearson Education, Inc.

Gheytasi, M., Azizifar, A., \& Gowhary, H. 2015. The effect of smartphone on the reading comprehension Proficiency of Iranian EFL Learners. Procedia-Social and Behavioral Sciences 199: 225-230. https://doi.org/10.1016/J.SBSPRO.2015.07.510.

Kadir, A. 2018. Pengaruh kompetensi dosen dan motivasi belajar terhadap kemampuan analisis statistika mahasiswa FTIK IAIN Kendari. Al-Izzah Jurnal Hasil-Hasil Penelitian 13(1): 1-15. http:/ /dx.doi.org/10.31332/ai.v13i1.886.

Keengwe, J., \& Georgina, D. 2012. The digital course training workshop for online learning and teaching. Education and Information Technologies 17(4): 365-379. https://doi.org/10.1007/s10639-011-9164-x.

Khusniyah, N., \& Hakim, L. 2019. Efektivitas pembelajaran berbasis daring: sebuah bukti pada pembelajaran bahasa Inggris. Jurnal Tatsqif, 17(1), 19-33. https://doi.org/10.20414/jtq.v17i1.667.

Mamattah, R., Selorm 2016. Students' perceptions of e-Learning. Thesis Degree of Master. Linköping University.

Martins, M. de L. 2015. How to effectively integrate technology in the foreign language classroom for learning and collaboration. Procedia - Social and Behavioral Sciences 174, 77-84. https://doi.org/10.1016/J.SBSPRO.2015.01.629.

Matthew B. Miles, A. Michael Huberman, \& Johnny Saldaña. 2014. Qualitative Data Analysis: A Methods Sourcebook and the Coding Manual for Qualitative Researchers. Thousand Oaks, CA: Sage Publications.

McCutcheon, K., Lohan, M., Traynor, M., \& Martin, D. 2015. A systematic review evaluating the impact of online or blended learning vs. face-to-face learning of clinical skills in undergraduate nurse education. Journal of Advanced Nursing 71(2), 255270.

Moleong, Lexy J. 2009. Metodologi Penelitian Kualitatif. Bandung: PT. Remadja Rosdakarya.

Muirhead, W. 2000. Online education in schools. International Journal of Educational Management 14(7): 315-324. https://doi.org/10.1108/09513540010378969.

Navarro, P., \& Shoemaker, J. 2000. Performance and perceptions of distance learners in cyberspace. American Journal of Distance Education 14(2): 15-35.

Nguyen, Tuan. 2015. The effectiveness of online learning: beyond no significant difference and future horizons. MERLOT Journal of Online Learning and Teaching 11(2): 309-319.

Qi, W. 2017. Evaluating a virtual collaborative environment for interactive distance teaching and learning: A Case study. Smart Innovation. Systems and Technologies, 11-18. https://doi.org/10.1007/978-3-319-50212-0_2.

Riffell, S., \& Sibley, D. 2005. Using web-based instruction to improve large undergraduate biology courses: An evaluation of a hybrid course format. Computers \& Education 44(3): 217-235.

Rovai, A. P., \& Jordan, H. 2004. Blended Learning and Sense of Community: A Comparative Analysis with Traditional and Fully Online Graduate Courses. The International Review of Research in Open and Distance Learning 5(2): 1-13.

Sintema, E. J. 2020. Effect of COVID-19 on the performance of grade 12 Students: Implications for STEM education. Eurasia Journal of Mathematics, Science and Technology Education, 16(7): 1-6. https://doi.org/10.29333/ejmste/7893.

Suyanto \& Jihad, A. 2013. Menjadi Guru Profesional (Strategi Meningkatkan Kualifikasi dan Kualitas Guru di Era Global). Jakarta: Esensi Erlangga Group.

Thamarana, S. 2016. Role of e-learning and virtual learning environment in english language learning role of e-learning and virtual learning environment in English. Research Scholar 1(August), 1-8. https://doi.org/10.13140/RG.2.1.4665.1122.

Walker, P.G.T., C. Whittaker., O. Watson., M. Baguelin., K.E.C. Ainslie., S. Bhatia., S. Bhatt., A. Boonyasiri., O. Boyd., L. Cattarino., Z. Cucunubá., G. Cuomo-Dannenburg., A. Dighe., C.A. Donnelly., I. Dorigatti., S. van Elsland., R. FitzJohn., S. Flaxman., H. Fu., K. Gaythorpe., L. Geidelberg., N. Grassly., W. Green., A. Hamlet., K. Hauck., D. Haw., S. Hayes., W. Hinsley., N. Imai., D. Jorgensen., E. Knock., D. Laydon., S. Mishra., G. Nedjati-Gilani., L.C. Okell., S. Riley., H. Thompson., J. Unwin., R. Verity., M. Vollmer., C. Walters., H. W. Wang., Y. Wang., P. Winskill., X. Xi., N.M Ferguson., 
\& A.C. Ghani. 2020. The global impact of COVID-19 and strategies for mitigation and suppression. Imperial College London: 1-19. https://doi.org/10.25561/77735.

Wekke, I. S., \& Hamid, S. 2013. Technology on language teaching and learning: A Research on Indonesian pesantren. ProcediaSocial and Behavioral Sciences 83, 585-589. https://doi.org/10.1016/J.SBSPRO.2013.06.111. 